\title{
ANALISIS PENERAPAN E-PROCUREMENT MENGGUNAKAN SISTEM PENGADAAN SECARA ELEKTRONIK: \\ STUDI KASUS PADA LAYANAN PENGADAAN SECARA ELEKTRONIK (LPSE) KEMENTERIAN KEUANGAN PAPUA BARAT
}

\author{
Cosmas Sakti Wijaya Adi \\ Kantor Pelayanan Perbendaharaan Negara Khusus Investasi \\ Alamat Korespondensi: cosmas.sakti@gmail.com
}

INFORMASI ARTIKEL

Diterima Pertama

14 Juni 2016

Dinyatakan Diterima

22 Maret 2017

KATA KUNCI:

E-Procurement, Transparency, Effectiveness, Efficiency, Implementation.

KLASIFIKASI JEL:

M150, H830, H570,0380

\begin{abstract}
ABSTRAK
Implementation of e-procurement in Indonesia is based on Presidential Decree no 54/2010 and its amendment. Ministry of Finance has developed LPSE which serves e-procurement, but not exclusively, to its offices in Indonesia by providing an office in each province in Indonesia. Implementation of $e$ procurement aims to increase accountability, transparency, effectiveness, efficiency and security of procurement. Using qualitative approach and descriptive technique, this study analyzes the implementation of e-procurement especially in LPSE of Ministry of Finance in West Papua. The result of this study shows that the implementation of e-procurement has met its purposes, increasing accountability, transparency, effectiveness, efficiency and security of procurement.
\end{abstract}

Implementasi e-procurement di Indonesia didasarkan pada Peraturan Presiden Nomor 54 Tahun 2010 dan perubahannya. Kementerian Keuangan telah mengembangkan Layanan Pengadaan Secara Elektronik (LPSE) yang menyediakan layanan e-procurement bagi, tetapi tidak terbatas pada kantorkantor di lingkup Kementerian Keuangan dengan membentuk kantor pada setiap provinsi di Indonesia. Implementasi $e$ procurement bertujuan untuk meningkatkan akuntabilitas, transparansi, efektivitas, efisiensi dan keamanan pengadaan barang dan jasa. Dengan menggunakan metode penelitian kualitatif dan teknik deskriptif, penelitian ini menganalisis implementasi e-procurement pada LPSE Kementerian Keuangan di Papua Barat. Hasil dari penelitian ini menunjukkan bahwa implementasi e-procurement telah memenuhi tujuannya yaitu, meningkatkan akuntabilitas, transparansi, efektivitas, efisiensi dan keamanan pengadaan barang dan jasa. 


\section{PENDAHULUAN}

\subsection{Latar Belakang}

Pengadaan barang dan jasa pemerintah sesuai dengan Peraturan Presiden Nomor 54 Tahun 2010 tentang Pengadaan Barang dan Jasa serta perubahannya diamanatkan untuk dilaksanakan secara elektronik. Sesuai amanat ini, Pemerintah membentuk Lembaga Kebijakan Pengadaan Pemerintah (LKPP) yang bertugas merumuskan peraturan di bidang pengadaan barang dan jasa serta membentuk suatu Layanan Pengadaan Barang dan Jasa secara Elektronik (LPSE). LKPP memberikan ruang bagi Kementerian/ Lembaga/ Satuan Kerja Perangkat Daerah/ Institusi (K/L/D/I) untuk membentuk Layanan Pengadaan Barang dan Jasa Secara Elektronik (LPSE) dengan menggunakan Sistem Pengadaan Secara Elektronik (SPSE) yang mengacu pada LKPP.

Kementerian Keuangan telah membentuk LPSE pada masing-masing provinsi di Indonesia untuk memberikan pelayanan pengadaan barang dan jasa secara elektronik bagi kantor-kantor vertikal Kementerian Keuangan dan kantor-kantor pemerintahan lainnya yang ingin menggunakan layanan tersebut. Salah satu kantor LPSE Kementerian Keuangan adalah LPSE Kementerian Keuangan Papua Barat. LPSE Kementerian Keuangan Papua Barat memberikan pelayanan pengadaan barang dan jasa bagi kantor-kantor vertikal Kementerian Keuangan dan kantor pemerintahan lainnya di wilayah Papua Barat yang mencakup 12 kabupaten dan 1 kota.

Provinsi Papua Barat merupakan provinsi yang mempunyai potensi perkembangan pembangunan yang tinggi. Wilayah yang luas, alam yang indah dan kekayaan alam yang melimpah menjadikan Papua sebagai wilayah Indonesia yang kaya. Salah satu potensi tersebut adalah destinasi wisata. Destinasi wisata di Papua Barat memicu perkembangan pembangunan di bidang ekonomi. Perkembangan dan potensi yang besar ini memerlukan suatu sarana yang mendukung proses pembangunan di Papua Barat yaitu proses pengadaan barang dan jasa. LPSE Kementerian Keuangan di Papua Barat merupakan salah satu wadah untuk mendukung proses pengadaan barang dan jasa di lingkup Kementerian Keuangan di wilayah Provinsi Papua Barat.

Pembangunan di Papua Barat yang menjadi salah satu prioritas pembangunan nasional membawa konsekuensi mengalirnya dana APBN ke wilayah Papua Barat. Aliran dana tersebut perlu didukung dengan pelaksanaan pengadaan barang dan jasa yang akuntabel, transparan, efektif, efisien dan aman sehingga tujuan pembangunan dapat tercapai. Keberadaan LPSE Kementerian Keuangan di Papua Barat bertujuan untuk mendukung pelaksanaan pengadaan barang dan jasa. Pertanyaan yang menarik untuk dicari jawabannya adalah apakah Sistem Pengadaan Secara Elektronik telah menyediakan pengadaan barang dan jasa secara efektif dan efisien. Sistem Pengadaan Barang dan Jasa secara elektronik yang efisien dan efektif dapat menghasilkan barang-barang publik yang lebih berkualitas sehingga dapat mengurangi beban APBN dan dapat mendukung pembangunan yang lebih baik di Papua Barat.

\subsection{Batasan Penelitian}

Penulis menyadari bahwa topik merupakan materi yang sangat luas dan kompleks cakupannya. Oleh karena itu, penulis membatasi pembahasan pada pengelolaan dan pelaksanaan pengadaan barang konstruksi melalui LPSE Kementerian Keuangan Papua Barat periode 2012-2015.

\subsection{Rumusan Masalah}

Penelitian ini dibuat atas hasil observasi awal atas keberadaan LPSE Kementerian Keuangan Papua Barat. Beberapa masalah yang dibahas dalam penelitian ini adalah: 1) apa dampak SPSE yang dijalankan oleh LPSE dalam proses pengadaan barang dan jasa di lingkup Kementerian Keuangan; 2) apakah SPSE menyediakan pengadaan barang dan jasa secara efektif dan efisien; dan 3) apa kendala yang dihadapi dalam penerapan SPSE pada LPSE Kementerian Keuangan Papua Barat serta bagaimana solusinya.

\subsection{Tujuan Penelitian}

Tujuan yang ingin dicapai melalui penelitian ini adalah: 1) untuk mengetahui praktik pelaksanaan pengadaan barang dan jasa melalui LPSE Kementerian Keuangan; 2) untuk mengetahui tingkat efisiensi dan efektivitas pengadaan barang dan jasa melalui LPSE Kementerian Keuangan; 3) untuk mengetahui kendala-kendala yang dihadapi LPSE Kementerian Keuangan di Papua Barat.

\subsection{Manfaat Penelitian}

Penulis berharap hasil yang didapat dari penelitian ini dapat memberikan masukan dan saran bagi pengelolaan LPSE secara umum dan LPSE Kementerian Keuangan secara khusus. Penulis juga berharap penelitian ini dapat memberikan masukan dalam peningkatan layanan LPSE Kementerian Keuangan dan peningkatan kualitas pengadaan barang dan jasa di Indonesia. 


\section{KERANGKA TEORI DAN PENGEM- BANGAN HIPOTESIS}

Teknologi informasi memanfaatkan internet sebagai media penyampaian data guna mendorong efisiensi pekerjaan dan mengurangi kesalahan yang mungkin dilakukan oleh manusia. Penggunaan sistem teknologi informasi pada proses pengadaan barang dan jasa diharapkan dapat mendorong efisiensi dalam pengadaan barang dan jasa. Selain itu, keamanan penyampaian informasi dan langkah-langkah pelaksanaan pengadaan barang dan jasa diharapkan juga meningkat sehingga dapat mengurangi kesalahan dalam proses pengadaan barang dan jasa.

\subsection{Pengadaan Barang dan Jasa Pemerintah}

Sutedi (2012) dalam Nurchana, Haryono, \& Adiono (2014) menjelaskan bahwa pengadaan barang dan jasa mencakup penjelasan dari seluruh proses sejak awal perencanaan, persiapan, perizinan, penentuan pemenang lelang, hingga tahap pelaksanaan dan proses administrasi dalam pengadaan barang, pekerjaan atau jasa. $^{1}$ Berdasarkan Peraturan Presiden Nomor 4 Tahun 2015 tentang Perubahan Keempat Perpres Nomor 54 Tahun 2010 tentang Pengadaan Barang dan Jasa Pemerintah, pengadaan barang/jasa pemerintah adalah kegiatan untuk memperoleh barang/jasa oleh Kementerian/ Lembaga/ Satuan Kerja Perangkat Daerah/ Institusi (K/L/D/I) yang prosesnya dimulai dari perencanaan kebutuhan sampai diselesaikannya seluruh kegiatan untuk memperoleh barang/jasa. Kiswara (2011) dalam Nugroho, Wanto, \& Trisnawati (2015) menyatakan bahwa pengadaan barang/jasa pemerintah merupakan usaha untuk memperoleh barang, jasa dan prasarana umum dalam waktu tertentu yang menghasilkan nilai terbaik bagi pemerintah maupun masyarakat. ${ }^{2}$

Pengadaan barang dan jasa pemerintah yang dilakukan melalui swakelola dan/atau pemilihan barang/jasa meliputi:

\section{a. Barang}

Barang dapat diartikan sebagai setiap benda baik berwujud maupun tidak berwujud, bergerak maupun tidak bergerak, yang dapat

1 A. R. Nurchana, et al., Efektivitas E-procurement dalam Pengadaan Barang/Jasa. Jurnal Administrasi Publik, 2014, hlm. 355-359.

2 R. S. Nugroho, et al., Pengaruh Implementasi Sistem Pengadaan Secara Elektronik (Eprocurement) terhadap Fraud Pengadaan Barang/Jasa Pemerintah. Jurnal Administrasi Publik, 2015, hlm.1905-1911. diperdagangkan, dipakai, dipergunakan atau dimanfaatkan oleh pengguna barang.

\section{b. Pekerjaan Konstruksi}

Pekerjaan konstruksi merupakan seluruh pekerjaan yang berhubungan dengan pelaksanaan konstruksi bangunan atau pembuatan wujud fisik lainnya. Pekerjaan konstruksi bangunan sendiri meliputi keseluruhan atau sebagian rangkaian kegiatan pelaksanaan yang mencakup pekerjaan arsitektural, sipil, mekanikal, elektrikal dan tata lingkungan beserta kelengkapannya untuk mewujudkan suatu bangunan.

\section{c. Jasa Konsultasi}

Jasa konsultasi merupakan jasa layanan profesional yang membutuhkan keahlian tertentu di berbagai bidang keilmuan yang mengutamakan adanya olah pikir (brainware).

\section{d. Jasa Lainnya}

Jasa lainnya adalah jasa yang membutuhkan kemampuan tertentu yang mengutamakan keterampilan (skillware) dalam suatu sistem tata kelola yang telah dikenal luas di dunia usaha untuk menyelesaikan suatu pekerjaan atau segala pekerjaan dan/atau penyediaan jasa selain jasa konsultasi. Contoh jasa lainnya adalah jasa boga, jasa impor/ekspor dan jasa penyedia tenaga kerja.

Prinsip-prinsip dalam pengadaan barang dan jasa pemerintah adalah (Yudiyatna, 2012): ${ }^{3}$

a. Efisien

Efisien berarti pengadaan barang/jasa harus diusahakan dengan menggunakan dana dan daya yang minimum untuk mencapai kualitas dan sasaran dalam waktu yang ditetapkan atau menggunakan dana yang telah ditetapkan untuk mencapai hasil dan sasaran dengan kualitas yang maksimum.

b. Efektif

Efektif berarti pengadaan barang/jasa harus sesuai dengan kebutuhan dan sasaran yang telah ditetapkan serta memberikan manfaat yang sebesar-besarnya.

c. Transparan

Transparan berarti semua ketentuan dan informasi mengenai pengadaan barang/jasa bersifat jelas dan dapat diketahui secara luas oleh penyedia barang/jasa yang berminat serta oleh masyarakat pada umumnya.

d. Terbuka dan Bersaing

Terbuka berarti pengadaan barang/jasa dapat diikuti oleh semua penyedia barang/jasa yang memenuhi persyaratan/ kriteria tertentu berdasarkan ketentuan dan prosedur yang jelas.

3 H. Yudiyatna, Buku Saku Pengadaan Barang/ Jasa, 2012. 
Bersaing berarti pengadaan barang/jasa harus dilakukan melalui persaingan yang sehat di antara sebanyak mungkin penyedia barang/jasa yang setara dan memenuhi persyaratan, sehingga dapat diperoleh barang/jasa yang ditawarkan secara kompetitif dan tidak ada intervensi yang mengganggu terciptanya mekanisme pasar dalam pengadaan barang/jasa.

\section{e. Adil/ tidak diskriminatif}

Adil/ tidak diskriminatif berarti adanya perlakuan yang sama dalam pengadaan barang/jasa bagi semua calon penyedia barang/jasa dan tidak mengarah untuk memberi keuntungan kepada pihak tertentu dengan tetap memperhatikan kepentingan nasional.

\section{f. Akuntabel}

Akuntabel adalah salah satu prinsip pengadaan barang/jasa yang berarti harus sesuai dengan aturan dan ketentuan yang terkait dengan pengadaan barang/jasa sehingga dapat dipertanggungjawabkan.

\subsection{E-procurement}

E-procurement merupakan proses pengadaan barang dan jasa pemerintah yang dilakukan secara elektronik terutama berbasis website atau internet (Udoyono, 2012).4 Willem (2012) dalam Damayanti, Domai, \& Wachid (2013) menyatakan bahwa pengadaan secara elektronik merupakan pelaksanaan pengadaan barang dan jasa dengan menggunakan jaringan elektronik (jaringan internet atau intranet) atau Electronic data interchange (EDI). ${ }^{5}$ European Commission (2010) menyatakan bahwa e-procurement merupakan suatu proses penyelenggaraan pemerintahan menggunakan komunikasi elektronik. ${ }^{6} \quad E$ procurement merujuk pada penggunaan informasi yang berbasis internet dan teknologi komunikasi untuk menjalankan proses pengadaan barang dan jasa oleh pemerintah (Vaidya, Sajeev, \& Callender, 2006). ${ }^{7}$ Secara umum, e-procurement merupakan

4 K. Udoyono, E-procurement dalam Pengadaan Barang dan Jasa untuk Mewujudkan Akuntabilitas di Kota Yogyakarta, 2012.

5 Damayanti, et al., Penerapan E-procurement dalam Proses Pengadaan Barang/Jasa di Kabupaten Malang, Jurnal Administrasi Publik, 2013, hlm. 139-146.

6 European Commission, Green Paper on Expanding the Use of E-Procurement in the EU, 2010.

7 K. Vaidya, et al., Critical Factors that Influence E-procurement Implementation Success in the penggunaan media komunikasi elektronik yang berupa internet sebagai media pelaksanaan pengadaan barang dan jasa.

Tabel 1. Perbedaan Pengadaan Barang dan Jasa Konvensional dan Elektronik

\begin{tabular}{|c|c|c|}
\hline Tahapan & Konvensional & Elektronik \\
\hline Pengumuman & Melalui website & Melalui Website \\
\hline $\begin{array}{l}\text { Pendaftaran dan } \\
\text { Pengambilan } \\
\text { dokumen }\end{array}$ & $\begin{array}{l}\text { Datang langsung } \\
\text { (tatap muka) }\end{array}$ & Download via web \\
\hline $\begin{array}{l}\text { Penjelasan } \\
\text { dokumen dan } \\
\text { perubahan } \\
\text { dokumen }\end{array}$ & $\begin{array}{l}\text { - Datang langsung } \\
\text { (tatap muka) } \\
\text { - Adendum } \\
\text { disampaikan } \\
\text { manual }\end{array}$ & $\begin{array}{l}\text { - Komunikasi online } \\
\text { (chatting) } \\
\text { - Berita acara } \\
\text { tertuang dalam } \\
\text { rekaman } \\
\text { komunikasi online } \\
\text { - Adendum di- } \\
\text { download via web }\end{array}$ \\
\hline $\begin{array}{l}\text { Dokumen } \\
\text { penawaran dan } \\
\text { pembukaan } \\
\text { dokumen } \\
\text { penawaran }\end{array}$ & $\begin{array}{l}\text { - Bentuk hardcopy } \\
\text { - Sampul tersegel } \\
\text { - Disampaikan } \\
\text { secara langsung } \\
\text { ke panitia } \\
\text { - Dibuka secara } \\
\text { manual }\end{array}$ & $\begin{array}{l}\text { - } \text { Berbentuk softcopy } \\
\text { - Dokumen } \\
\text { disandikan } \\
\text { (encrypt) } \\
\text { - Dikirim (upload) } \\
\text { melalui web } \\
\text { - Dibuka (decrypt) } \\
\text { secara elektronik }\end{array}$ \\
\hline $\begin{array}{l}\text { Evaluasi } \\
\text { penawaran }\end{array}$ & $\begin{array}{l}\text { - } \text { Cara evaluasi } \\
\text { dilakukan } \\
\text { manual oleh } \\
\text { panitia } \\
\text { - Berita acara } \\
\text { datang langsung } \\
\text { (tatap muka) }\end{array}$ & $\begin{array}{l}\text { - } \text { Cara evaluasi } \\
\text { dilakukan manual } \\
\text { oleh panitia } \\
\text { dengan cara } \\
\text { mendownload file } \\
\text { penawaran } \\
\text { terlebih dahulu } \\
\text { - Berita acara } \\
\text { diunduh oleh } \\
\text { penyedia via web }\end{array}$ \\
\hline $\begin{array}{l}\text { Evaluasi } \\
\text { kualifikasi }\end{array}$ & $\begin{array}{l}\text { Cara evaluasi } \\
\text { dilakukan manual } \\
\text { oleh panitia } \\
\text { Berita acara datang } \\
\text { langsung (tatap } \\
\text { muka) }\end{array}$ & $\begin{array}{l}\text { Cara evaluasi } \\
\text { dilakukan manual } \\
\text { oleh panitia } \\
\text { Berita acara diunduh } \\
\text { oleh penyedia via } \\
\text { web }\end{array}$ \\
\hline $\begin{array}{l}\text { Pengumuman } \\
\text { pemenang }\end{array}$ & $\begin{array}{l}\text { Datang dan lihat } \\
\text { langsung }\end{array}$ & $\begin{array}{l}\text { Diumumkan di web } \\
\text { dan dikirimkan via } e \text { - } \\
\text { mail }\end{array}$ \\
\hline $\begin{array}{l}\text { Sanggah hasil } \\
\text { lelang }\end{array}$ & $\begin{array}{l}\text { Datang langsung } \\
\text { (tatap muka) dan } \\
\text { surat menyurat }\end{array}$ & Komunikasi online \\
\hline
\end{tabular}

Sumber: hasil olahan penulis

Keunggulan e-procurement yang diharapkan adalah (European Commission, 2010):

a. Meningkatkan akses masyarakat dan transparansi

Penggunaan internet dan teknologi informasi sebagai basis e-procurement memberikan akses yang luas bagi masyarakat umum maupun penyedia barang dan jasa yang berminat mengikuti lelang. Pencarian informasi lelang pengadaan barang dan jasa pemerintah melalui internet bisa dilakukan dengan cepat oleh para calon penyedia barang. Hal ini akan meningkatkan akses penyedia

Public Sector, Journal of Public Procurement, Volume 6, 2006, hlm. 70-99. 
barang dan jasa atas pengadaan barang dan jasa yang dijalankan oleh pemerintah. Akses yang lebih baik dapat mengurangi batasan-batasan dalam pengadaan barang dan jasa, baik batasan tempat/ lokasi maupun zona waktu. Pengadaan barang dan jasa pemerintah dapat diakses dan diikuti oleh penyedia barang dan jasa di seluruh Indonesia.

Penggunaan internet sebagai basis $e$ procurement di samping memberikan keuntungan bagi penyedia barang dan jasa, juga dapat memberikan akses masyarakat dalam mengawasi kinerja pemerintah terutama dalam pelaksanaan APBN. Masyarakat dapat mengawasi proyek pemerintah terutama dalam proses pengadaan barang dan jasa pemerintah sehingga dapat mendukung prinsip transparansi yang ingin dicapai dalam proses pengadaan barang dan jasa pemerintah.

b. Mengurangi biaya administrasi baik material maupun prosedural

Dibandingkan dengan proses pengadaan barang dan jasa yang menggunakan kertas secara manual, konsep e-procurement memberikan keuntungan penghematan biaya administrasi baik material maupun prosedural. Penghematan biaya administrasi dapat dirasakan oleh pemerintah maupun penyedia barang dan jasa. Berkas dan dokumen pengadaan barang dan jasa yang dalam paper based procurement harus disediakan dalam bentuk hardcopy, dapat dihilangkan dan disimpan dalam bentuk softcopy baik dalam cloud system maupun offline system. Pengurangan biaya administrasi juga terdapat dalam bentuk pengurangan biaya pengiriman dokumen maupun transportasi.

Pengurangan biaya yang dirasakan dalam penerapan e-procurement adalah pemotongan birokrasi pemerintahan dan prosedur pelelangan. Cita-cita yang ingin dicapai dalam e-procurement adalah pemotongan birokrasi dalam proses pengadaan barang dan jasa sehingga waktu pelaksanaan proses pengadaan barang dan jasa khususnya dalam lelang maupun pembelian menjadi lebih singkat sehingga dapat mendorong percepatan belanja negara dan selanjutnya dapat mendorong pembangunan ekonomi yang lebih cepat dan baik.

c. Meningkatkan efisiensi pengadaan barang dan jasa

Penerapan e-procurement dapat menghilangkan batasan-batasan informasi bagi seluruh penyedia barang dan jasa. Transparansi informasi pengadaan barang dan jasa mendorong persaingan usaha oleh para penyedia barang dan jasa dengan lebih kompetitif. Persaingan usaha yang lebih baik dapat mendorong harga kontrak dalam penawaran pengadaan barang dan jasa menjadi lebih efisien.

Neef (2001) dalam Rahayu, Saleh, \& Prasetyo (2013) memberikan pendapat bahwa paling tidak terdapat delapan manfaat e-procurement yaitu: ${ }^{8}$

a. Biaya transaksi yang lebih rendah;

b. Pemesanan yang lebih cepat;

c. Pilihan terhadap vendor yang lebih luas;

d. Proses yang terstandarisasi sehingga pengadaan barang lebih efisien;

e. Kontrol yang lebih baik terhadap proses pengeluaran pengadaan barang dan tingkat kepatuhan pegawai yang lebih baik;

f. Menyediakan akses internet yang lebih luas kepada pembeli;

g. Kertas kerja yang lebih sedikit dan mengurangi pengulangan prosedur administratif;

h. Membantu penyusunan ulang terhadap proses pengadaan barang.

Siahaya (2012) dalam Nurchana menyatakan tujuan e-procurement yaitu:

a. Meningkatkan transparansi dan akuntabilitas;

b. Meningkatkan akses pasar dan persaingan usaha;

c. Meningkatkan tingkat efisiensi proses pengadaan;

d. Mendukung proses monitoring dan audit;

e. Memenuhi kebutuhan akses informasi terkini.

Willem (2012) dalam Damayanti, Domai, \& Wachid (2013) menyatakan bahwa E-procurement mempunyai beberapa jenis yaitu:

1. E-tendering

E-tendering merupakan pemilihan penyedia barang dan jasa yang dilakukan secara terbuka dan diikuti oleh semua penyedia barang dan jasa yang terdaftar pada sistem pengadaan secara elektronik.

\section{E-bidding}

E-bidding merupakan pelaksanaan pengadaan barang dan jasa dengan cara penyampaian informasi dan/atau data pengadaan dari penyedia barang dan jasa, dimulai dari pengumuman sampai dengan pengumuman hasil pengadaan, dilakukan melalui media elektronik.

\section{E-catalogue}

E-catalogue adalah sistem informasi elektronik yang memuat daftar, jenis, spesifikasi teknis dan harga barang tertentu dari berbagai penyedia barang dan jasa

8 Rahayu, et al., Implementasi Kebijakan Eprocurement untuk Mewujudkan Efisiensi dan Transparansi, Jurnal Administrasi Publik Fakultas Ilmu Administrasi Universitas Brawijaya, 2013. 


\section{E-purchasing}

E-purchasing adalah tata cara pembelian barang dan jasa melalui sarana e-catalogue.

Pelaksanaan e-procurement yang menggunakan teknologi informasi dalam proses transaksi dan pertukaran informasi membutuhkan sistem pengadaan barang dan jasa yang terintegrasi sehingga pembangunan sistem informasi teknologi yang terintegrasi mutlak diperlukan. Sistem pengadaan barang dan jasa memerlukan pula internet sebagai basis komunikasi dari penyedia barang, masyarakat dan pemerintah. E-procurement dapat dilaksanakan dengan optimal dengan dukungan sumber daya yang mencukupi. Sumber daya yang dibutuhkan dalam pembangunan sistem e-procurement yang memadai adalah:

\section{Software}

\section{a. Sistem e-procurement}

Sistem yang memadai dalam mendukung e-procurement merupakan sistem yang berjalan pada platform web based. Sistem ini merupakan sistem yang mudah diaplikasikan dan murah. Pengembang sistem tidak memerlukan pengembangan aplikasi khusus yang digunakan untuk menjalankan sistem, namun dapat menggunakan browser internet yang sudah ada dalam sistem operasi.

\section{b. Antivirus}

Sistem yang memadai sebagai dasar $e$ procurement membutuhkan pula keamanan sistem. Sistem keamanan tersebut tidak lepas dari gangguan virus, cracker, maupun celah (bug) sistem yang bisa dimanfaatkan dalam kejahatan cyber (Ndikron, Suryaningsih, \& Santoso, 2016).

\section{Hardware}

\section{a. Komputer/Smartphone}

Penggunaan web-based application dalam e-procurement maupun platform membutuhkan komputer maupun smartphone guna mengakses informasi yang tersedia dan turut serta dalam e-procurement. Kebutuhan komputer/smartphone dalam rangka e-procurement diperlukan mengingat proses e-procurement merupakan proses paperless di mana semua proses dilaksanakan menggunakan sistem teknologi informasi dengan internet sebagai media pengiriman data.

\section{b. Jaringan internet/telepon.}

Jaringan internet merupakan salah satu komponen pokok dalam proses pengadaan barang dan jasa menggunakan sistem e-procurement. Jaringan internet diperlukan sebagai media penyampaian informasi, pengiriman dokumen maupun pengambilan dokumen (download dokumen).

Jaringan telepon sebagai salah satu sumber penyedia jaringan internet juga digunakan sebagai solusi force majeur apabila sewaktu-waktu jaringan internet mengalami gangguan. Jaringan telepon juga digunakan sebagai media komunikasi secara langsung apabila jaringan internet (surel, chatting) tidak berfungsi.

\section{c. Jaringan listrik}

Jaringan listrik dibutuhkan tidak hanya oleh sistem e-procurement tetapi juga oleh para pengguna.

\subsection{Efektivitas}

Draft (2008) menyatakan bahwa efektivitas merupakan tingkat pengukuran organisasi dalam mencapai tujuan. ${ }^{9}$ Satries (2011) dalam Nurchana, Haryono, \& Adiono (2014) menyatakan bahwa efektivitas merupakan hubungan antara keluaran dengan sasaran yang harus dicapai yaitu semakin besar kontribusi keluaran yang dihasilkan terhadap nilai pencapaian sasaran tersebut, maka dapat dikatakan efektif pula unit tersebut. Sementara itu, Ulum (2009) dalam Nurchana, Haryono, \& Adiono (2014) menyatakan bahwa efektivitas tidak menyatakan tentang berapa besar biaya yang telah dikeluarkan untuk mencapai tujuan tersebut, tetapi efektivitas hanya melihat apakah suatu program atau kegiatan telah mencapai tujuan yang telah ditetapkan. Besaran kontribusi yang lebih besar dapat dimaknai sebagai semakin efektif unit tersebut. Dapat ditarik suatu pengertian bahwa efektivitas merupakan tingkat pencapaian tujuan oleh suatu organisasi.

\subsection{Efisiensi}

Draft (2008) menyatakan bahwa efisiensi berhubungan dengan pemanfaatan sumber daya ekonomi seminimal mungkin untuk mencapai tujuan yang diinginkan. Menurut Hansen \& Mowen (2007) biaya merupakan satuan pengukuran efisiensi yang paling penting. ${ }^{10}$ Dalam perhitungan efisiensi suatu organisasi dalam pencapaian tujuan, biaya seminimal mungkin merupakan pengukuran yang paling mudah. Namun, biaya bukanlah satusatunya satuan pengukuran efisiensi. Efisiensi terkait pula dengan sumber daya ekonomi lainnya seperti waktu, manusia dan sumber daya material lainnya. Dengan demikian dapat disimpulkan

9 R. L. Draft, Organization Theory and Design Tenth Edition, Cengage Learning, 2008.

10 Hansen, et al., Managerial Accounting, Thomson South Western, 2007. 
bahwa efisiensi berkaitan dengan penggunaan masukan minimal untuk mencapai tujuan.

\section{METODOLOGI PENELITIAN}

\subsection{Pendekatan Penelitian}

Pendekatan penelitian yang dilakukan adalah pendekatan kualitatif. Menurut Strauss dan Carbin (1997) dalam Sujarweni (2014) penelitian kualitatif adalah jenis penelitian yang menghasilkan penemuan-penemuan yang tidak dapat dicapai dengan menggunakan prosedurprosedur statistik atau dengan cara kuantifikasi lainnya. Penelitian kualitatif dapat digunakan untuk meneliti kehidupan masyarakat, sejarah, tingkah laku, fungsionalisasi organisasi, aktivitas sosial dan lain-lain

Pendekatan kuantitatif digunakan untuk menguji validitas dan reliabilitas survei yang dilakukan. Survei dilakukan kepada pegawai yang yang menjadi panitia lelang pada kantor-kantor vertikal Kementerian Keuangan di wilayah Papua Barat dan kantor-kantor yang telah bekerja sama dengan LPSE Kementerian Keuangan Papua Barat.

\subsection{Jenis Data dan Cara Pengumpulan Data}

Penelitian ini menggunakan data primer dan sekunder berupa data kualitatif. Data kualitatif dianalisis dengan menggunakan metode analisis deskriptif. Data primer diperoleh dengan melakukan survei dengan instrumen wawancara untuk mendapatkan tanggapan dari responden. Survei dilakukan melalui wawancara dengan para pegawai LPSE Kementerian Keuangan dan panitia pengadaan barang dan jasa.

Kuesioner dibagikan kepada kantor-kantor vertikal Kementerian Keuangan di Papua Barat. Kuesioner sebanyak 30 buah telah disebar pada tanggal 4 Februari 2016 dan 25 diantaranya telah diisi dan dikembalikan. Kuesioner dibagikan kepada seluruh panitia pengadaan barang dan jasa atau pegawai pada kantor vertikal Kementerian Keuangan di wilayah Papua Barat (populasi). Materi kuesioner dibagi menjadi 4 bagian yaitu: 1) kemudahan operasi SPSE, 2) keamanan lelang elektronik, 3) efisiensi dan transparansi, 4) pelayanan yang diberikan LPSE.

Kuesioner tersebut diukur menggunakan skala Likert sebagai skala untuk mengukur interpretasi responden terhadap pernyataan dalam kuesioner. Skala Likert digunakan untuk mengukur tingkat setuju dan tidak setuju responden terhadap suatu objek atau pernyataan. Skala Likert yang digunakan dalam kuesioner penelitian ini menggunakan lima respons yaitu Sangat Tidak
Setuju (STS), Tidak Setuju (TS), Ragu-Ragu (RR), Setuju (S) dan Sangat Setuju (SS).

Terdapat dua pengujian data kuesioner yaitu uji validitas dan uji reliabilitas. Uji validitas dilakukan dengan melakukan korelasi bivariate antara masing-masing skor indikator dengan total skor konstruk (Ghozali, 2013). ${ }^{11}$ Uji validitas dilakukan menggunakan metode uji dua arah (2tailed) dengan koefisien korelasi Pearson. Uji reliabilitas terhadap kuesioner dalam penelitian ini dilakukan untuk mengukur keandalan jawaban atas pernyataan yang diajukan dalam kuesioner. Keandalan atau reliabilitas diukur dengan menggunakan uji statistik Cronbach's Alpha pada SPSS. Suatu kuesioner dikatakan reliabel atau handal jika jawaban seseorang terhadap pernyataan adalah konsisten atau stabil dari waktu ke waktu (Ghozali, 2013).

Data sekunder diperoleh dari studi pustaka peraturan perundang-undangan yang berlaku khususnya dalam bidang pengadaan barang dan jasa pemerintah, hasil dari olahan dan kutipan karya tulis, literatur, skripsi, jurnal dan buku serta data pendukung lainnya.

\subsection{Metode Pengolahan Data}

Metode analisis yang akan digunakan adalah analisis deskriptif yaitu menguraikan implementasi penerapan e-procurement melalui Sistem Pengadaan Secara Elektronik oleh LPSE Kementerian Keuangan Papua Barat dan kendalakendala yang dihadapi dalam menjalankan LPSE. Data kuesioner akan diolah secara kuantitatif dan dideskripsikan dengan tambahan wawancara yang dilakukan oleh penulis. Analisis deskriptif dilakukan untuk menjelaskan pelaksanaan $e$ procurement pada LPSE Kementerian Keuangan Papua Barat serta mengetahui permasalahan yang ada dan solusi yang dibutuhkan.

\section{HASIL PENELITIAN}

\subsection{Analisis Deskriptif}

a. Kemudahan operasi SPSE

Bagian pertama kuesioner berisi pertanyaan seputar kemudahan operasi SPSE. Hasil kuesioner menunjukkan bahwa SPSE mudah untuk dioperasikan oleh panitia lelang. Secara umum (88\%) responden setuju bahwa SPSE memberikan kemudahan dalam pelaksanaan proses lelang.

11 Ghozali, Aplikasi Analisis Multivariate dengan Program IBM SPSS 21 Edisi Ketujuh, Semarang: Badan Penerbit Undip, 2013. 
Tabel 2. Sebaran Frekuensi atas Kuesioner tentang Kemudahan Operasi SPSE

\begin{tabular}{|c|c|c|c|c|c|c|c|}
\hline \multirow{2}{*}{ No } & \multirow{2}{*}{$\begin{array}{l}\text { Pertanyaar } \\
\text { no }\end{array}$} & STS & TS & RR & $s$ & Ss & $\begin{array}{l}\text { Total } \\
\text { Jumlah }\end{array}$ \\
\hline & & Jumlah & Jumiah & $\frac{J u m a h}{\%}$ & Jumlah & Jumlah & \\
\hline 1 & P1_1 & 0 & 0 & 0 & 21 & 4 & 25 \\
\hline & & $0 \%$ & $\frac{0 \%}{1}$ & $\frac{0 \%}{3}$ & $\frac{84 \%}{17}$ & $\frac{16 \%}{4}$ & $\frac{100 \%}{25}$ \\
\hline & PI_z & $0 \%$ & $4 \%$ & $12 \%$ & $68 \%$ & $16 \%$ & $100 \%$ \\
\hline 3 & P1_3 & 0 & $\frac{1}{4 \%}$ & $\begin{array}{c}5 \\
20 \%\end{array}$ & $\begin{array}{l}14 \\
56 \%\end{array}$ & $\frac{5}{20 \%}$ & $\begin{array}{c}25 \\
1\end{array}$ \\
\hline 4 & P1_4 & 0 & 0 & 3 & 16 & 6 & 25 \\
\hline & & $0 \%$ & $0 \%$ & $\frac{12 \%}{2}$ & $\frac{64 \%}{17}$ & $\frac{24 \%}{6}$ & $\frac{100 \%}{25}$ \\
\hline 5 & P1_5 & $0 \%$ & $0 \%$ & $8 \%$ & $68 \%$ & $24 \%$ & $100 \%$ \\
\hline $\mathbf{P}$ & & & & $\begin{array}{r}13 \\
10 \%\end{array}$ & $68 \%$ & $20 \%$ & $\begin{array}{r}125 \\
100 \%\end{array}$ \\
\hline
\end{tabular}

Sumber: hasil pengolahan data kuesioner

Kuesioner pada bagian ini terdiri dari 5 pertanyaan yang akan digunakan lebih lanjut sebagai dasar penyusunan wawancara. Pertanyaan pada bagian ini digunakan untuk melihat kemudahan operasi SPSE. Rincian pertanyaan adalah sebagai berikut:

1. Saya memahami aplikasi Sistem Pengadaan Secara Elektronik (SPSE) yang diselenggarakan LPSE Kementerian Keuangan;

2. Prosedur pengoperasian SPSE mudah dipahami;

3. Mudah untuk membuat lelang elektronik dalam sistem ini;

4. Sistem ini membantu saya dalam menyeleksi penyedia barang dan jasa;

5. SPSE memberikan kemudahan dalam pengumuman lelang elektronik.

Pada analisis deskriptif, hasil kuesioner dikelompokkan menjadi 3 kutub yaitu setuju yang terdiri jawaban sangat setuju dan setuju, ragu-ragu dan tidak setuju yang terdiri dari jawaban sangat tidak setuju dan tidak setuju.

Kemudahan operasi SPSE diwakili oleh pernyataan bahwa operator dan panitia pengadaan barang dan jasa telah memahami aplikasi SPSE yang diselenggarakan LPSE Kementerian Keuangan. Panitia pengadaan barang/jasa dan operator juga setuju bahwa prosedur pengoperasian SPSE mudah dipahami. Di samping itu, SPSE memberikan kemudahan dalam hal pembuatan lelang elektronik, pengumuman lelang elektronik serta membantu dalam menyeleksi penyedia barang dan jasa.

b. Keamanan lelang elektronik

Bagian kedua kuesioner, berisi pertanyaan mengenai keamanan lelang elektronik. Hasil kuesioner menunjukkan bahwa SPSE memberikan keamanan bagi pengguna SPSE. Secara umum (87\%), responden setuju bahwa lelang elektronik aman.

Kuesioner terdiri dari 3 pertanyaan yang akan digunakan lebih lanjut sebagai dasar penyusunan wawancara. Pertanyaan pada bagian ini digunakan untuk melihat keamanan lelang elektronik. Rincian pertanyaan adalah sebagai berikut:

1. SPSE mengurangi kontak panitia dan penyedia;

2. SPSE mengurangi manipulasi pemenang oleh panitia;

3. Saya yakin dengan keamanan lelang elektronik menggunakan SPSE.

Tabel 3. Sebaran Frekuensi atas Kuesioner Keamanan Lelang Elektronik

\begin{tabular}{|c|c|c|c|c|c|c|c|}
\hline \multirow{3}{*}{ No } & \multirow{3}{*}{$\begin{array}{c}\text { Pertanyaan } \\
\text { no }\end{array}$} & STS & TS & RR & $S$ & SS & Total \\
\hline & & Jumlah & Jumlah & Jumlah & Jumlah & Jumlah & Jumlah \\
\hline & & $\%$ & $\%$ & $\%$ & $\%$ & $\%$ & $\%$ \\
\hline \multirow{2}{*}{1} & \multirow{2}{*}{ P2_1 } & 0 & 0 & 2 & 15 & 8 & 25 \\
\hline & & $0 \%$ & $0 \%$ & $8 \%$ & $60 \%$ & $32 \%$ & $100 \%$ \\
\hline \multirow{2}{*}{2} & \multirow{2}{*}{ P2_2 } & 0 & 0 & 5 & 13 & 7 & 25 \\
\hline & & $0 \%$ & $0 \%$ & $20 \%$ & $52 \%$ & $28 \%$ & $100 \%$ \\
\hline \multirow{2}{*}{3} & \multirow{2}{*}{ P2_3 } & 0 & 0 & 3 & 17 & 5 & 25 \\
\hline & & $0 \%$ & $0 \%$ & $12 \%$ & $68 \%$ & $20 \%$ & $100 \%$ \\
\hline \multicolumn{2}{|c|}{ Jumlah } & 0 & 0 & 10 & 45 & 20 & 75 \\
\hline \multicolumn{2}{|c|}{ Persentase } & $0 \%$ & $0 \%$ & $13 \%$ & $60 \%$ & $27 \%$ & $100 \%$ \\
\hline
\end{tabular}

Sumber: Hasil pengolahan data kuesioner

Responden setuju bahwa SPSE mengurangi kontak panitia dan penyedia. Berkurangnya kontak panitia dan penyedia mendorong berkurangnya manipulasi pemenang oleh panitia. Para responden juga yakin dengan keamanan lelang elektronik.

\section{c. Efisiensi dan transparansi}

Bagian ketiga kuesioner berisi pertanyaan mengenai efisiensi dan transparansi. Hasil kuesioner menunjukkan bahwa penggunaan SPSE dalam e-procurement meningkatkan efisiensi dan transparansi. Sebanyak 91\% responden memberikan jawaban bahwa efisiensi dan transparansi lelang meningkat. Peningkatan efisiensi dan transparansi terlihat dari pengurangan biaya administratif dan kompetisi harga.

Tabel 4. Sebaran Frekuensi atas Kuesioner Efisiensi dan Transparansi

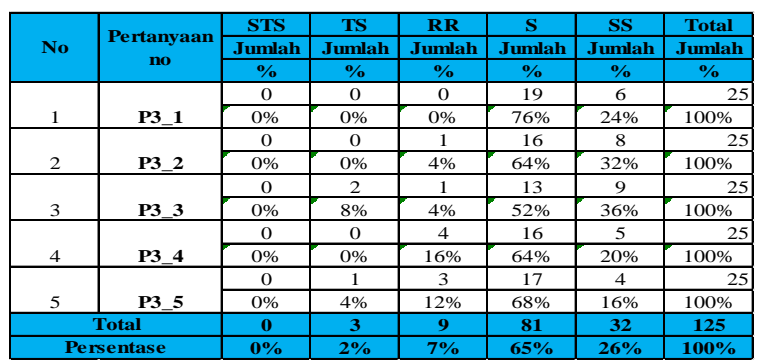

Sumber: Hasil pengolahan data kuesioner

Kuesioner terdiri dari 5 pertanyaan yang digunakan lebih lanjut sebagai dasar penyusunan wawancara. Pertanyaan pada bagian ini digunakan untuk melihat efisiensi dan transparansi lelang elektronik. Rincian pertanyaan adalah sebagai berikut:

1. SPSE mengurangi biaya administratif seperti biaya pengumuman lelang, transportasi dan penggandaan dokumen; 
2. Lelang elektronik menciptakan persaingan harga yang kompetitif;

3. Pelelangan elektronik memberikan kesempatan bagi semua penyedia untuk mengikuti lelang;

4. Pencarian pengumuman lelang elektronik mudah diperoleh pada SPSE;

5. Masyarakat dapat mengawasi lelang elektronik dengan mudah melalui SPSE.

Panitia lelang pengadaan barang dan jasa setuju bahwa SPSE mengurangi biaya administratif seperti biaya pengumuman lelang, transportasi dan penggandaan dokumen. Panitia juga setuju bahwa lelang elektronik memberikan persaingan harga yang lebih kompetitif. Hal ini karena pelelangan elektronik memberikan kesempatan bagi semua penyedia untuk mengikuti lelang.

Panitia lelang dalam kuesioner yang telah dibagikan secara umum setuju bahwa pencarian pengumuman lelang elektronik mudah diperoleh pada SPSE. Di samping itu, masyarakat dapat lebih berperan aktif dengan mengawasi lelang elektronik melalui SPSE.

d. Pelayanan yang diberikan petugas LPSE Kementerian Keuangan Papua Barat

Bagian keempat berisi pertanyaan mengenai pelayanan yang diberikan petugas LPSE Kementerian Keuangan Papua Barat. Hasil distribusi frekuensi berdasarkan pertanyaan pada bagian 4 menunjukkan bahwa sebanyak 78\% responden setuju akan ketersediaan layanan yang diberikan oleh LPSE Kementerian Keuangan Papua Barat.

Tabel 5. Sebaran Frekuensi atas Kuesioner Pelayanan yang diberikan Petugas LPSE Kementerian Keuangan Papua Barat

\begin{tabular}{|c|c|c|c|c|c|c|c|}
\hline \multirow{3}{*}{ No. } & \multirow{3}{*}{$\begin{array}{c}\text { Pertanyaan } \\
\text { No. }\end{array}$} & STS & TS & RR & $\mathrm{S}$ & SS & Total \\
\hline & & Jumlah & Jumlah & Jumlah & Jumlah & Jumlah & Jumlah \\
\hline & & $\%$ & $\%$ & $\%$ & $\%$ & $\%$ & $\%$ \\
\hline \multirow{2}{*}{1} & \multirow{2}{*}{ P4_1 } & 0 & 0 & 5 & 15 & 5 & 25 \\
\hline & & $0 \%$ & $0 \%$ & $20 \%$ & $60 \%$ & $20 \%$ & $100 \%$ \\
\hline \multirow{2}{*}{2} & \multirow{2}{*}{ P4_2 } & 0 & 1 & 4 & 16 & 4 & 25 \\
\hline & & $0 \%$ & $4 \%$ & $16 \%$ & $64 \%$ & $16 \%$ & $100 \%$ \\
\hline \multirow{2}{*}{3} & \multirow{2}{*}{ P4_3 } & 1 & 0 & 4 & 15 & 5 & 25 \\
\hline & & $4 \%$ & $0 \%$ & $16 \%$ & $60 \%$ & $20 \%$ & $100 \%$ \\
\hline \multirow{2}{*}{4} & \multirow{2}{*}{ P4_4 } & 1 & 1 & 4 & 13 & 6 & 25 \\
\hline & & $4 \%$ & $4 \%$ & $16 \%$ & $52 \%$ & $24 \%$ & $100 \%$ \\
\hline \multirow{2}{*}{5} & \multirow{2}{*}{ P4_5 } & 1 & 0 & 5 & 15 & 4 & 25 \\
\hline & & $4 \%$ & $0 \%$ & $20 \%$ & $60 \%$ & $16 \%$ & $100 \%$ \\
\hline \multirow{2}{*}{\multicolumn{2}{|c|}{ entase }} & 3 & 2 & 22 & 74 & 24 & 125 \\
\hline & & $2 \%$ & $2 \%$ & $18 \%$ & $59 \%$ & $19 \%$ & $100 \%$ \\
\hline
\end{tabular}

Sumber: Hasil pengolahan data kuesioner

Kuesioner terdiri dari 5 pertanyaan yang akan digunakan lebih lanjut sebagai dasar penyusunan wawancara. Pertanyaan untuk melihat efisiensi dan transparansi lelang elektronik. Rincian pertanyaan adalah sebagai berikut:

1. Pegawai LPSE Sorong selalu tanggap atas permasalahan yang saya sampaikan;

2. Mudah untuk bertemu dengan pegawai LPSE Sorong;
3. LPSE Kementerian Keuangan memberikan pelatihan SPSE bagi penyedia barang dan jasa;

4. LPSE Kementerian Keuangan mempunyai SDM yang mencukupi untuk melayani pengguna;

5. LPSE Kementerian Keuangan Sorong memiliki fasilitas lengkap guna mendukung pelayanan bagi pengguna.

Data distribusi pada kuesioner yang telah diterima menunjukkan responden secara umum setuju bahwa pegawai LPSE Kementerian Keuangan Papua Barat di Sorong selalu tanggap atas permasalahan yang disampaikan. Para panitia juga merasa mudah untuk bertemu dengan pegawai LPSE. Dalam hal pelatihan, pegawai LPSE Kementerian Keuangan Papua Barat memberikan pelatihan bagi penyedia barang dan jasa. Para panitia lelang juga merasa fasilitas dan sumber daya manusia pada LPSE Kementerian Keuangan Papua Barat mencukupi untuk melayani pengguna.

Pada kuesioner tersebut terdapat pertanyaan terbuka yang bebas diisi oleh responden dengan pertanyaan "Menurut Anda, apa permasalahan yang anda hadapi terkait lelang secara elektronik melalui LPSE Kementerian Keuangan? Apa saran Anda?". Terdapat 3 permasalahan utama berdasarkan kuesioner tersebut yaitu:

1) Permasalahan jaringan internet

Responden mengeluhkan jaringan internet yang kurang mendukung pelaksanaan lelang elektronik menggunakan SPSE. Beberapa responden menuliskan kesulitan untuk menjalankan lelang elektronik karena jaringan internet yang kurang memadai.

2) Permasalahan sumber daya

Beberapa responden menuliskan bahwa di kantor masing-masing kekurangan SDM guna menjalankan lelang secara elektronik.

3) Permasalahan kurangnya pemahaman SPSE

Beberapa responden menyatakan pelatihan seputar aplikasi masih kurang. Kurangnya pelatihan membuat panitia masih kesulitan dalam menjalankan lelang elektronik dan merasa lelang elektronik terlalu rumit. 


\subsection{Implementasi E-procurement Kementerian Keuangan Papua Barat}

LPSE Kementerian Keuangan Papua Barat didirikan sejak tahun 2011, namun karena kendala sarana dan prasarana yang belum mendukung, LPSE Kementerian Keuangan Papua Barat baru dapat menjalankan fungsinya untuk melayani lelang elektronik mulai tahun 2012 dengan memberikan pelayanan berupa pendaftaran penyedia barang dan jasa, panitia lelang, memberikan konsultasi dan layanan training bagi kantor-kantor vertikal Kementerian Keuangan serta penyedia barang dan jasa tentang bagaimana mekanisme pengoperasian Sistem Pengadaan Secara Elektronik Kementerian Keuangan.

LPSE Kementerian Keuangan Papua Barat di Sorong menyelenggarakan pelayanan pengadaan di wilayah Papua Barat. Wilayah tersebut mencakup 13 kabupaten dan kota. Satuan kerja yang dilayani oleh LPSE Kementerian Keuangan Papua Barat adalah satuan kerja yang merupakan kantor vertikal Kementerian Keuangan di Papua Barat. Layanan LPSE Kementerian Keuangan Papua Barat juga dapat dimanfaatkan oleh satuan kerja pada kementerian lain dan pemerintah daerah setempat.

Tabel 6. Kota dan Kabupaten dalam Wilayah Kerja LPSE Kementerian Keuangan Papua Barat

\begin{tabular}{|c|l|}
\hline No & \multicolumn{1}{|c|}{ Kabupaten/Kota } \\
\hline 1 & Kota Sorong \\
\hline 2 & Kabupaten Fakfak \\
\hline 3 & Kabupaten Kaimana \\
\hline 4 & Kabupaten Manokwari \\
\hline 5 & Kabupaten Manokwari Selatan \\
\hline 6 & Kabupaten Maybrat \\
\hline 7 & Kabupaten Pegunungan Arfak \\
\hline 8 & Kabupaten Raja Ampat \\
\hline 9 & Kabupaten Sorong \\
\hline 10 & Kabupaten Sorong Selatan \\
\hline 11 & Kabupaten Tambrauw \\
\hline 12 & Kabupaten Teluk Bintuni \\
\hline 13 & Kabupaten Teluk Wondama \\
\hline
\end{tabular}

Sumber: Data LPSE Kementerian Keuangan

Sejak tahun 2012 sampai dengan 2015 terdapat total 34 lelang elektronik. Tahun 2013 merupakan tahun dengan lelang elektronik yang paling banyak. Lelang tersebut dilaksanakan oleh kantor vertikal Kementerian Keuangan dan kantor yang telah melakukan MoU dengan LPSE Kementerian Keuangan Papua Barat.
Gambar 1. Lelang Elektronik LPSE Kementerian Keuangan Papua Barat

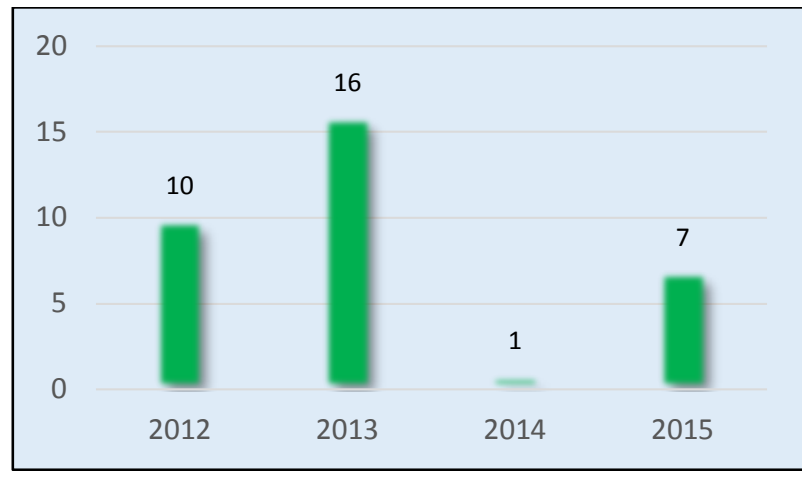

Sumber: Data LPSE Kementerian Keuangan Papua Barat

Hasil wawancara lebih lanjut terhadap implementasi e-procurement pada LPSE Kementerian Keuangan Papua Barat dapat dijelaskan sebagai berikut:

a. Kemudahan

Wawancara lebih lanjut menggambarkan bahwa terdapat kemudahan oleh panitia dan peserta lelang. Kemudahan meliputi teknis pengadaan secara elektronik yaitu proses pembuatan lelang, pengumuman lelang, proses pelaksanaan lelang dan kemudahan dalam administratif lelang berupa berkurangnya dokumen lelang yang perlu disiapkan oleh panitia dan peserta lelang.

Pengumuman lelang sampai dengan pemenang lelang dilakukan pada website LPSE Kementerian Keuangan. Peserta lelang dapat menemukan pengumuman lelang yang diselenggarakan dengan mudah melalui fasilitas pencarian lelang yang bisa diikuti. Pada lelang manual, panitia lelang membuat pengumuman lelang pada media cetak nasional. Pengumuman lelang pada media massa membutuhkan waktu dan mekanisme pembayaran yang membutuhkan persyaratan administratif.

Panitia dimudahkan dalam teknis lelang seperti pembuatan jadwal lelang, upload dokumen lelang dan aanwijzing. Pada lelang manual, panitia pengadaan barang dan jasa membuat pertemuan dengan peserta lelang pada tempat dan waktu tertentu.

Panitia lelang menyatakan bahwa SPSE mudah untuk dioperasikan. Menu-menu yang ada pada SPSE lengkap dan LPSE Kementerian Keuangan juga menyediakan buku panduan yang dapat diunduh. Pegawai LPSE Kementerian Keuangan telah memberikan pelatihan dan sosialisasi bagi panitia sehingga risiko kesalahan operasi lelang elektronik dapat dikurangi. 
Berdasarkan hasil wawancara, salah satu kemudahan dari SPSE adalah tahap aanwijzing, dimana panitia dan penyedia tidak melakukan tatap muka langsung. Hal ini mengurangi potensi terjadinya kontak fisik sehingga panitia dapat memberikan tanggapan atas pertanyaan aanwijzing dengan lebih bebas dan tanpa tekanan. SPSE memberikan kemudahan bagi panitia untuk mengawasi kemajuan dan kontrol atas pelaksanaan lelang di mana saja melaui koneksi internet.

Bagi penyedia, SPSE memberikan kemudahan pencarian pengumuman lelang. Melalui fasilitas ini penyedia dapat mencari lelang yang dikehendaki, misalnya lelang yang berada pada kota Sorong. SPSE juga memberikan informasi bagi para penyedia terkait lelang-lelang yang mungkin dapat diikuti oleh penyedia. Pada lelang manual, penyedia barang dan jasa harus mencari di media massa maupun datang langsung ke kantor pemerintahan untuk mencari lelang yang tersedia sehingga membutuhkan waktu dan biaya. Kelemahan pengumuman pada media cetak yaitu penyedia yang mengikuti lelang merupakan penyedia yang membaca informasi media cetak tersebut.

\section{b. Peningkatan keamanan transaksi}

Potensi kecurangan pada lelang manual muncul karena kurangnya keamanan dan kerja sama antara penyedia dengan panitia. Potensi tersebut dapat ditekan melalui penerapan $e$ procurement melalui SPSE.

Dokumen penawaran oleh penyedia dikumpulkan dan dimasukkan dalam kotak yang ada pada kantor panitia lelang. Meskipun kotak tersebut disegel, kemungkinan kecurangan dapat terjadi untuk menjatuhkan penyedia yang tidak dikehendaki dengan cara menghilangan dokumen yang bersangkutan. SPSE mengeliminasi kemungkinan ini, karena dokumen penawaran hanya dapat dibuka oleh panitia pada saat jadwal lelang telah berada pada tahap pembukaan dokumen penawaran.

Hasil wawancara menunjukkan bahwa lelang menggunakan SPSE memberikan keamanan bagi panitia dan peserta lelang. Hal ini karena lelang menggunakan SPSE dilengkapi dengan aplikasi enkripsi data yang dibuat oleh Lembaga Sandi Negara sehingga mengurangi potensi pembukaan dokumen penawaran oleh pihak yang tidak berhak. Subdirektorat Layanan Pengguna Pusat LPSE Kementerian Keuangan menyatakan bahwa penyedia maupun panitia lelang tidak dapat membuka database secara langsung karena user dibatasi kewenangannya.
Dokumen penawaran hanya bisa dibuka oleh panitia lelang dengan menggunakan aplikasi Apendo yang dibuat oleh Lembaga Sandi Negara guna mengamankan dokumen penawaran. Aplikasi Pengamanan Dokumen untuk Peserta lelang (Apendo Peserta) pada Layanan Pengadaan Secara Elektronis (LPSE), merupakan hasil kerja sama antara Lembaga Sandi Negara (Lemsaneg) dan Lembaga Kebijakan Pengadaan Barang/Jasa Pemerintah (LKPP). Apendo Peserta digunakan untuk mengenkripsi atau menyandi dokumen penawaran yang dibuat oleh peserta lelang sebelum diupload ke server LPSE. Apendo Peserta khusus diberikan untuk Peserta Lelang yang telah terdaftar di LPSE.

Dalam lelang manual, panitia dapat melihat dokumen penawaran penyedia yang telah masuk dalam kotak lelang dan membocorkannya kepada penyedia yang diajak bekerja sama untuk merubah dokumen penawaran dengan harga penawaran yang lebih rendah daripada penyedia lain. Hasil wawancara dengan panitia lelang GKN Sorong menyatakan bahwa berkurangnya tatap muka antara panitia dan penyedia pada lelang elektronik membawa pengaruh positif bagi pelaksanaan lelang karena tidak ada kegiatan transaksional dan suap menyuap pada proyek tersebut.

\section{c. Biaya}

Lelang elektronik menggunakan SPSE dapat mengurangi biaya-biaya yang diperlukan guna melaksanakan pengadaan barang dan jasa, antara lain: 1) biaya pengumuman lelang dapat dihilangkan, 2) biaya penggandaan dokumen lelang dapat dihilangkan, 3) biaya penggandaan dokumen penawaran dapat dihilangkan, 4) biaya transportasi oleh panitia maupun penyedia untuk tatap muka dapat dihilangkan. Berdasarkan hasil kuesioner, lelang elektronik menggunakan SPSE memberikan persaingan harga yang lebih kompetitif sehingga efisien dalam pelaksanaan pengadaan barang dan jasa.

Lelang manual maupun elektronik pada dasarnya tetap membutuhkan dokumen kualifikasi serta dokumen penawaran sebagai persyaratan lelang. Perbedaan antara lelang manual dan lelang elektronik adalah wujud dari dokumen-dokumen tersebut. Pada lelang manual, dokumen-dokumen tersebut harus disediakan dalam bentuk hardcopy oleh penyedia barang dan jasa dan diserahkan kepada panitia lelang. Pada lelang elektronik, dokumen kualifikasi diunggah ke dalam server SPSE oleh penyedia barang dan jasa pada saat melakukan pendaftaran dan dokumen penawaran diunggah ke dalam server SPSE pada saat dilaksanakannya lelang. 
Hasil wawancara dengan Subdirektorat Layanan Pengguna Pusat LPSE Kementerian Keuangan menyebutkan bahwa dalam lelang elektronik sudah tidak memerlukan biaya administratif seperti penggandaan kertas. Salah satu fokus LPSE Kementerian Keuangan adalah pembinaan kepada kelompok kerja (pokja) untuk membuat dokumen lelang yang lebih efisien sehingga mendukung pemilihan spesifikasi barang yang lebih efisien dan barang yang dibeli benarbenar dipakai. Lelang elektronik maupun manual mengharuskan penyedia melampirkan dokumen administratif seperti surat domisili, NPWP dan Surat Izin Usaha Perusahaan. Dalam lelang elektronik, penyampaian dokumen ini dimudahkan dengan online, penyedia barang menyampaikan softcopy dokumen tersebut ke dalam server SPSE. Panitia dimudahkan dalam memilih penyedia barang dan jasa yang lolos dalam tahap persyaratan administratif karena dalam sistem SPSE menampilkan dokumen-dokumen tersebut.

\section{d. Transparansi dan persaingan}

SPSE mendorong persaingan yang terbuka dan adil bagi semua penyedia barang dan jasa. Penyedia dapat mengikuti lelang yang diselenggarakan pada LPSE Kementerian Keuangan secara nasional sesuai dengan spesifikasi dan kualifikasi yang ditentukan dan dapat melakukan pengawasan atas pelaksanaan lelang. Penyedia di seluruh Indonesia dapat mengikuti lelang yang diselenggarakan dengan menghilangkan faktor geografis sebagai batasan dalam memperoleh informasi. Penyedia yang berada di Jawa akan mendapatkan informasi yang sama dengan penyedia di daerah Maluku sehingga penyedia barang dan jasa dapat bersaing secara bebas.

SPSE memberikan akses kepada masyarakat untuk dapat melihat proses pelaksanaan lelang tanpa perlu menggunakan user id maupun password sehingga dapat mengurangi potensi kecurangan yang dilakukan oleh panitia lelang dan penyedia barang/jasa. Hasil kuesioner memberikan jawaban bahwa ransparansi lelang elektronik menggunakan SPSE lebih baik daripada lelang manual karena pengawasan oleh panitia, peserta dan masyarakat meningkat.

\section{e. Akuntabilitas}

Akuntabel merupakan salah satu prinsip pengadaan barang dan jasa yang harus dipenuhi. Lelang elektronik dengan menggunakan SPSE perlu menyediakan dan memberikan kepastian akuntabilitas bagi pengguna, auditor dan semua pihak yang mempunyai kepentingan atas pertanggungjawaban para pihak yang terlibat dalam lelang elektronik.

Terdapat 2 aspek dalam akuntabilitas yang perlu disediakan oleh SPSE. Aspek pertama adalah ketersediaan dokumen bukti. Beberapa dokumen yang perlu disediakan dalam lelang antara lain dokumen pakta integritas yang disediakan oleh sistem. Aspek kedua adalah bukti penyelenggaraan lelang. SPSE memberikan ringkasan lelang yang berisi isi pelaksanaan lelang secara detil. Hal ini bisa digunakan sebagai alat bukti dan dokumen otentik lelang.

SPSE memberikan ringkasan proses lelang yang telah diselenggarakan mulai dari pembuatan lelang, jadwal, pengumuman lelang, pembukaan dokumen penawaran, evaluasi penyedia dan lainlain. Ringkasan lelang merupakan ringkasan yang dapat dicetak oleh panitia barang dan jasa dan menjadi bukti otentik penyelenggaraan lelang.

Ringkasan lelang merupakan salah satu alat akuntabilitas lelang elektronik menggunakan SPSE. SPSE juga mempunyai superuser yang merupakan user-id level tinggi yang dapat mengakses seluruh isi database lelang elektronik. Superuser tersebut diberikan bagi auditor maupun penyidik untuk melakukan penyelidikan atas penyelenggaraan lelang elektronik.

\subsection{SPSE dalam Efektivitas dan Efisiensi Pengadaan Barang dan Jasa}

Berdasarkan data yang diperoleh dan wawancara yang dilakukan, secara keseluruhan pelaksanaan lelang elektronik menggunakan SPSE dapat meningkatkan efektivitas pengadaan barang dan jasa. Data pelaksanaan lelang elektronik menyebutkan bahwa sebanyak $80 \%$ lelang dapat terselenggara dengan baik sedangkan $20 \%$ lelang tidak terselenggara karena berbenturan dengan aturan yang ada seperti kurangnya jumlah penyedia yang mengikuti lelang.

Lelang dikatakan efektif apabila telah terlaksana sesuai dengan rencana dan tujuan dapat tercapai. Lelang elektronik memberikan kemungkinan keberhasilan lelang dan pengadaan barang dan jasa yang lebih besar dari lelang secara manual. Dengan demikian dapat disimpulkan bahwa lelang secara elektronik menggunakan SPSE telah efektif dan efisien.

Terdapat 34 paket lelang yang telah dijalankan menggunakan Sistem Pengadaan Secara Elektronik pada LPSE Kementerian Keuangan Papua Barat. Dari 34 paket lelang tersebut, terdapat 7 paket lelang yang dinyatakan gagal dan 27 paket lelang yang berhasil. Paket lelang yang berhasil dapat dilihat pada proses lelang yang telah 
selesai dilaksanakan dan telah dilaksanakan penandatanganan kontrak oleh satuan kerja dan pihak penyedia.

Gambar 2. Lelang pada LPSE Kementerian Keuangan Papua Barat

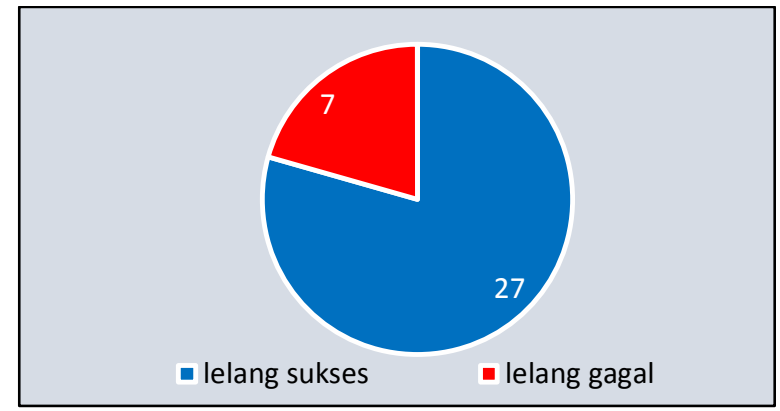

Sumber: Data LPSE Kementerian Keuangan Papua Barat

Dari 7 penyebab gagalnya proses lelang, 2 diantaranya adalah adanya revisi pagu dan perubahan metode lelang, penyebab ini masih bisa ditolerir karena merupakan hal yang dikehendaki oleh panitia pengadaan barang dan jasa. Panitia membatalkan proses lelang karena terdapat alasan yang bukan merupakan kegagalan sistem. Penyebab gagalnya proses lelang yang lain adalah kurangnya jumlah penawar terhadap paket lelang tersebut.

Lelang elektronik mendukung efisiensi lelang pengadaan barang dan jasa dalam hal biaya yang harus dikeluarkan oleh panitia maupun penyedia untuk menyelenggarakan lelang. Lelang elektronik tidak membutuhkan tempat khusus untuk proses lelang dan bertemu langsung. Hal tersebut dapat mengurangi biaya transportasi dan sewa menyewa tempat. Di samping itu, lelang secara elektronik dapat mengurangi biaya pembuatan dokumen dan penggandaan karena panitia dan penyedia cukup mengunggah softcopy dokumen lelang dan dokumen penawaran ke SPSE.

Efisiensi tersebut mengakibatkan adanya kompetisi harga yang adil dan bersaing bagi para calon penyedia barang dan jasa. Kuesioner memberikan hasil bahwa mayoritas responden setuju bahwa lelang elektronik menggunakan SPSE dapat meningkatkan efisiensi dan transparansi prose lelang.

\subsection{Kendala dan Permasalahan Penerapan E-Procurement pada LPSE Kementerian Keuangan Papua Barat}

\subsubsection{Internal}

Kendala internal yang dihadapi dalam penerapan e-procurement pada LPSE Kementerian Keuangan Papua Barat adalah keterbatasan sumber daya manusia yaitu tidak memiliki pegawai tetap namun merupakan pegawai yang diperbantukan dari kantor-kantor vertikal Kementerian Keuangan di wilayah Sorong sehingga pelaksanaan pelayanan kurang maksimal. Pegawaipegawai tersebut mempunyai tugas fungsi pokok pada kantor masing-masing sehingga jika terjadi penumpukan pekerjaan, tugas pada kantor vertikal masing-masing akan diselesaikan terlebih dahulu sebelum menjalankan tugas pada LPSE. Permasalahan kebutuhan SDM sebenarnya dapat diselesaikan dengan menempatkan pegawai LPSE Kementerian Keuangan pada kantor LPSE Kementerian Keuangan di daerah dengan mengirimkan minimal satu pegawai sebagai pegawai tetap pada LPSE Kementerian Keuangan di daerah. Berdasarkan hasil wawancara dengan admin agency pada LPSE Kementerian Keuangan Papua Barat, usulan permintaan pegawai definitif telah diajukan kepada LPSE Kementerian Keuangan Pusat.

Kendala berikutnya terkait dengan SDM adalah kurangnya keahlian dalam bidang pengadaan barang dan jasa serta keterampilan pengoperasian SPSE. Seluruh pegawai LPSE Kementerian Keuangan Papua Barat sampai dengan tahun 2015 belum memiliki sertifikat pengadaan barang dan jasa meskipun dalam proses pelayanan bagi para pengguna SPSE serta dalam tugas pokok fungsi, para pegawai LPSE Kementerian Keuangan tidak diharuskan memiliki sertifikat pengadaan barang dan jasa. Dalam kenyataannya, beberapa panitia yang belum berpengalaman dalam pengadaan barang dan jasa sering mengajukan pertanyaan dan meminta bantuan panduan pengadaan barang dan jasa maupun dalam menjalankan SPSE. Dalam hal ini, sertifikasi bagi pegawai LPSE Kementerian Keuangan Papua Barat menjadi penting untuk memberikan jawaban yang tepat dan sesuai dengan peraturan perundang-undangan yang berlaku. Kurangnya keahlian dalam bidang pengadaan barang dan jasa juga terkait dengan pengoperasian aplikasi SPSE. Training bagi pegawai LPSE Kementerian Keuangan Papua Barat dilaksanakan setiap awal tahun yang bersifat penyegaran penggunaan aplikasi. Penambahan frekuensi training bagi pegawai LPSE Kementerian Keuangan Papua Barat sangat berguna untuk pelaksanaan tugas lelang.

Sarana dan prasarana pada LPSE Kementerian Keuangan Papua Barat telah mencukupi baik secara jumlah maupun kelengkapannya yang digunakan oleh para pegawai LPSE untuk memberikan pelayanan kepada pengguna sistem. Sarana dan prasarana ini juga dapat digunakan oleh panitia maupun penyedia yang menjalankan 
lelang elektronik. Hambatan sarana dan prasarana yang ada pada LPSE Kementerian Keuangan Papua Barat adalah belum mempunyai jaringan telepon.

\subsubsection{Eksternal}

Kendala eksternal yang dihadapi dalam penerapan e-procurement pada LPSE Kementerian Keuangan Papua Barat adalah jaringan listrik yang sering mengalami pemadaman listrik secara bergilir. Sistem Pengadaan Secara Elektronik LPSE Kementerian Keuangan memiliki pusat server di Jakarta dan para pengguna dapat mengakses sistem melalui jaringan komputer masing-masing. Hal ini menjadi kendala bagi penyedia dan panitia lelang dalam mengikuti jadwal proses lelang yang ada di mana lelang akan tetap berjalan sesuai jadwal yang ada pada pusat server SPSE meskipun tidak ada proses lelang yang gagal karena pemadaman listrik bergilir. Beberapa penyedia tidak dapat mengikuti jadwal lelang yang ada karena mengalami pemadaman listrik. Pemadaman listrik bergilir yang dilakukan di wilayah Papua Barat dapat mengganggu pelaksanaan proses lelang maupun pelayanan LPSE.

LPSE Kementerian Keuangan Papua Barat yang berlokasi di Gedung Keuangan Negara Sorong dapat menggunakan uninterruptible power supply (UPS) yang milik satker GKN Sorong yang berguna sebagai cadangan listrik dalam kondisi aliran listrik padam. LPSE Kementerian Keuangan Papua Barat dapat menyediakan layanan bagi para panitia dan penyedia yang terkendala oleh pemadaman listrik agar dapat tetap mengikuti dan menjalankan proses lelang.

Hambatan eksternal berikutnya yang dialami adalah kurangnya pengetahuan panitia dan penyedia seputar SPSE dan proses lelang menurut peraturan perundang-undangan. Hal ini dikarenakan kurangnya pelatihan dan sosialisasi yang dilakukan oleh LPSE Kementerian Keuangan Pusat maupun LPSE Kementerian Keuangan di Papua Barat. Kurangnya pengetahuan dan keterampilan panitia dan penyedia menjadi kendala pelaksanaan proses lelang yang berkualitas.

Penggunaan internet sebagai media pelaksanaan lelang elektronik juga menjadi hambatan bagi pelaksanaan lelang elektronik di Papua Barat. Jaringan internet merupakan komponen yang penting dalam pelaksanaan $e$ procurement karena jaringan internet digunakan untuk mengakses website dan server SPSE. Jaringan internet juga digunakan untuk mengunggah dokumen kualifikasi dan dokumen penawaran ke server SPSE. Kendala jaringan internet di wilayah Papua Barat yang kurang stabil dan cenderung lambat serta tidak meratanya fasilitas di masing- masing kota dan kabupaten di wilayah Papua Barat terkait jaringan internet dapat menjadi kendala pelaksanaan proses lelang.

Berdasarkan hasil wawancara, kantor-kantor pemerintahan menyatakan bahwa SDM menjadi salah satu kendala yang dihadapi, kurangnya jumlah pegawai dan kurangnya pegawai yang memiliki sertifikat pengadaan barang dan jasa menjadi kendala yang harus dihadapi oleh kantorkantor tersebut. Hal ini dapat mendorong terhambatnya proses pengadaan barang dan jasa khususnya dalam proses pelaksanaan lelang pengadaan barang dan jasa pada kantor tersebut.

\section{KESIMPULAN DAN SARAN}

Implementasi pengadaan barang dan jasa secara elektronik melalui SPSE pada LPSE Kementerian Keuangan Papua Barat membawa dampak positif bagi proses pengadaan barang dan jasa. Pelaksanaan lelang elektronik mendorong tercapainya tujuan-tujuan pengadaan barang dan jasa serta mendukung prinsip-prinsip pengadaan barang dan jasa. Pelaksanaan lelang elektronik menggunakan SPSE memberikan kemudahan bagi para pengguna dalam teknis pelaksanaan lelang secara sistem dan teknis pelaksanaan lelang seperti penatausahaan dokumen penawaran. Pelaksanaan lelang secara elektronik membawa keuntungan ekonomis berupa peningkatan efisiensi pelaksanaan lelang yang memberikan dampak positif bagi pelaksanaan pengelolaan keuangan negara.

Implementasi e-procurement pada LPSE Kementerian Keuangan Papua Barat terdapat kendala internal dan eksternal. Kendala internal berupa kurangnya SDM yang dimiliki oleh LPSE Kementerian Keuangan Papua Barat dan kurangnya sertifikasi pengadaan barang dan jasa serta kurangnya pelatihan operasi SPSE.

Kendala eksternal yang dihadapi meliputi pemadaman jaringan listrik yang sering terjadi, kurangnya pengetahuan penyedia dan panitia lelang, jaringan internet yang kurang memadai dan kurangnya SDM yang kompeten dalam pengadaan barang dan jasa.

Permasalahan yang dihadapi oleh LPSE Kementerian Keuangan Papua Barat merupakan permasalahan yang mendasar. Permasalahan tersebut dapat diatasi melalui serangkaian langkah yang komprehensif, antara lain:

a. Pemakaian data lelang sebagai masukan perencanaan anggaran

Data lelang yang telah dilakukan oleh satuan kerja pada kantor vertikal Kementerian Keuangan di Papua Barat dapat dijadikan referensi bagi 
pejabat pengadaan barang/jasa atau PPK dalam menentukan HPS yang digunakan sebagai dasar penyusunan Rencana Kerja dan Anggaran Kementerian/ Lembaga (RKA-KL). Penggunaan data lelang sebagai bagian penyusunan RKA-KL dapat membantu meningkatkan akurasi penyusunan anggaran tahun anggaran berikutnya.

b. Sosialisasi bagi satuan kerja non Kementerian Keuangan

Salah satu tujuan penyelenggaraan lelang elektronik menggunakan SPSE adalah terwujudnya lelang elektronik bagi seluruh kantor pemerintah. LPSE Kementerian Keuangan Pusat perlu bekerja sama dengan LPSE Kementerian Keuangan Papua Barat untuk menyelenggarakan sosialisasi dan pengenalan LPSE kementerian Keuangan kepada kantor-kantor pemerintahan pada wilayah Papua Barat sehingga pengguna layanan dapat bertambah.

c. Sosialisasi bagi penyedia barang dan jasa

Sosialisasi bagi penyedia barang dan jasa perlu dilakukan oleh LPSE Kementerian Keuangan Papua Barat untuk dapat meningkatkan jumlah penyedia yang terdaftar pada SPSE. Peningkatan jumlah penyedia terdaftar diharapkan dapat meningkatkan persaingan pada proses lelang sehingga dapat menghasilkan lelang yang efisien.

\section{d. Perbaikan SDM organisasi}

LPSE Kementerian Keuangan perlu membentuk pegawai definitif pada LPSE Kementerian Keuangan di daerah termasuk Papua Barat sehingga fokus pekerjaan oleh pegawai LPSE Kementerian Keuangan di daerah dapat lebih terjamin dan pelayanan pengadaan barang dan jasa menjadi prioritas utama sehingga proses pengadaan barang dan jasa menjadi lebih lancar dan tidak terbebani tugas lainnya.

\section{e. Sertifikasi}

Kebutuhan sertifikasi pengadaan barang dan jasa bagi pegawai LPSE Kementerian Keuangan tidak wajib, namun sertifikasi dapat membantu pegawai LPSE Kementerian Keuangan dalam menjalankan pelayanan dengan lebih baik.

f. Pelatihan bagi pegawai LPSE, panitia dan penyedia barang dan jasa

Pelatihan yang menyeluruh tentang SPSE bagi petugas LPSE Kementerian Keuangan Papua Barat, panitia pengadaan barang dan jasa lingkup Kementerian Keuangan dan penyedia barang dan jasa dapat mengurangi risiko gagal lelang akibat kesalahan dalam pengoperasian SPSE.

\section{IMPLIKASI DAN KETERBATASAN}

Penulis sadar bahwa penelitian ini masih memiliki keterbatasan. Perbaikan pada penelitian selanjutnya dapat memperbaiki hasil yang diperoleh. Keterbatasan dalam penelitian ini antara lain:

a. Keterbatasan komponen pernyataan dalam kuesioner. Penyusunan pertanyaan pada kuesioner mungkin belum memberikan pandangan yang mendalam apabila tidak diikuti dengan pengambilan data dari sumber lain seperti wawancara dan data pendukung.

b. Skala ganjil dalam penentuan skala Likert untuk mengukur jawaban responden memiliki kelemahan penilaian atas penentuan nilai tengah. Skala likert genap dapat menghilangkan jawaban ragu-ragu sehingga diharapkan dapat memberikan jawaban yang lebih pasti.

c. Keterbatasan akses data dalam mengambil data dan observasi lapangan. Faktor geografis menjadi penghambat penelitian untuk lebih mendalam terhadap objek penelitian. Pada penelitian selanjutnya, perlu dipertimbangkan faktor geografis dalam melakukan penelitian.

\section{PENGHARGAAN}

Penyusunan penelitian ini tidak terlepas dari bantuan berbagai pihak. Oleh karena itu penulis ingin mengucapkan terima kasih kepada para pihak yang telah memberikan kontribusi berupa bantuan data dan informasi serta sumbang saran dalam menyusun penelitian ini.

Penelitian ini merupakan penelitian yang dilakukan oleh penulis pribadi dan disusun sesuai dengan ketentuan penulisan karya tulis ilmiah. Penulis sadar akan kemungkinan kesalahan dalam melakukan penelitian ini dan bertanggung jawab atas kesalahan-kesalahan dalam penelitian ini serta membuka penuh kritik dan saran dari pembaca.

\section{DAFTAR PUSTAKA}

Damayanti, A. I., Domai, T., \& Wachid, A. (2013). Penerapan E-procurement dalam Proses Pengadaan Barang/Jasa di Kabupaten Malang. Jurnal Administrasi Publik, hlm. 139146.

Draft, R. L. (2008). Organization Theory and Design Tenth Edition. Cengage Learning.

European Commission. (2010). Green Paper on Expanding The use of e-procurement in the EU. 
Ghozali, I. (2013). Aplikasi Analisis Multivariate dengan Program IBM SPSS 21 edisi ketujuh. Semarang: Badan Penerbit Undip.

Hansen, D. R., \& Mowen, M. M. (2007). Managerial Accounting. Thomson South Western.

Ndikron, Suryaningsih, M., \& Santoso, R. S. (2016). Implementasi E-procurement di Universitas Diponegoro.

Nugroho, R. S., Wanto, A. H., \& Trisnawati. (2015). Pengaruh Implementasi Sistem Pengadaan Secara Elektronik (E-procurement) terhadap Fraud Pengadaan Barang/Jasa Pemerintah. Jurnal Administrasi Publik, hlm. 1905-1911.

Nurchana, A. R., Haryono, B. S., \& Adiono, R. (2014). Efektivitas E-procurement dalam Pengadaan Barang/Jasa. Jurnal Administrasi Publik, hlm. 355-359.

Rahayu, T. P., Saleh, C., \& Prasetyo, W. Y. (2013). Implementasi Kebijakan E-procurement untuk Mewujudkan Efisiensi dan Transparansi. Jurnal Administrasi Publik Fakultas Ilmu Administrasi Universitas Brawijaya.

Sujarweni, W. V. (2014). Metodologi Penelitian. Yogyakarta: Pustaka Baru Press.

Udoyono, K. (2012). E-procurement dalam Pengadaan Barang dan Jasa untuk Mewujudkan Akuntabilitas di Kota Yogyakarta.

Vaidya, K., Sajeev, A., \& Callender, G. (2006). Critical Factors that Influence E-procurement Implementation Success in the Public Sector. Journal of Public Procurement volume 6, hlm. 70-99.

Yudiyatna, H. (2012). Buku Saku Pengadaan Barang/Jasa. 